\title{
Hindsight as Foresight: Virgilian Retrospective Prophecy in Coopers Hill and The Destruction of Troy
}

\author{
Ian Calvert ${ }^{1}$
}

Published online: 4 January 2018

(C) The Author(s) 2017. This article is an open access publication

\begin{abstract}
This article discusses how the Virgilian intertexts of the stag hunt in the 1642 edition of Coopers Hill support the interpretation of the passage as a commentary on the trial and execution of the Earl of Strafford, and how they allow Denham to criticize Charles I's involvement in Strafford's death. Despite this criticism, other texts, including Denham's revised (1653/5) edition of the poem, subsequently adapted the stag-hunt episode to commemorate Charles's own trial and execution. The false presentation of the 1653/5 Coopers Hill as an edition that prints an original, authentic version of the poem from 1640 draws on the Virgilian technique of retrospective prophecy to make its status as a commentary on Charles's execution more explicit. Denham repeated this technique in The Destruction of Troy (1656), which heavily revised an excerpt from his 1630s manuscript translation of Aeneid II-VI, and asserts the composition date of this earlier version in order to 'foretell' Charles's execution. Analysing these Virgilian post eventum prophecies shows how both texts simultaneously censure and mourn Charles I, and also identifies increasingly self-recriminatory elements to Denham's own royalism.
\end{abstract}

\section{Introduction}

John Denham's two most significant literary projects, Coopers Hill and his translations from Virgil, exist in multiple manuscript and published versions that he

Ian Calvert

egicc@bristol.ac.uk

1 Department of English, University of Bristol, 3/5 Woodland Road, Clifton, Bristol BS8 1TB, UK 
revised periodically throughout his career. ${ }^{1}$ They both helped to popularize an aesthetic Augustanism: the attempt 'to find an equivalent in English of those ideal properties of style' that writers in the early modern period found in Virgil's versification and clarity of expression, hence Robert Herrick's account of Denham's 'brave, bold, and sweet Maronian [Virgilian] Muse' in his commendatory poem on Coopers Hill and John Dryden's claim that Denham's poetry provided 'the exact Standard of good Writing'. ${ }^{2}$ Each project has also been placed at the head of respective literary traditions that became highly influential during the long eighteenth century. ${ }^{3}$ These were topographical poetry in the case of Coopers Hill and, with regard to his Virgil, a mode of translation that abandoned 'that servile path' of 'tracing word by word, and line by line' in favour of representing the animating spirit of the text. ${ }^{4}$

Coopers Hill and Denham's first published Virgil translation, The Destruction of Troy (1656, but deriving from the manuscript rendering of Aeneid II-VI that Denham produced in the $1630 \mathrm{~s}),{ }^{5}$ have, in addition, attracted considerable attention for the commentary they offer on contemporary politics. The precise nature of

\footnotetext{
${ }^{1}$ In this article I retain the taxonomy of the Coopers Hill editions delineated by B. O Hehir in Expans'd Hieroglyphicks: A Critical Edition of Sir John Denham's Coopers Hill, Berkeley, 1969 (henceforth EH); that is, I refer to the 1642 edition of the poem, its manuscript predecessors and its reissues dated 1643 and 1650 as the ' $\mathrm{A}$ ' Text, and the 1653 edition, its 1655 reissue with added prefatory material, and the slightly revised version of 1668 as the 'B' Text. All quotations from Coopers Hill are from the relevant original editions, but line numbers have been supplied from $E H$. Quotations from Denham's Virgil are taken from Early Augustan Virgil: Translations by Denham, Godolphin, and Waller, ed. R. Sowerby, Lewisburg, 2010 (henceforth EAV). Denham's other poetry is cited from The Poetical Works of Sir John Denham, ed. T. H. Banks, 2nd edn, Hamden, 1969. For ease of reference, and because Sowerby has discussed how it is not possible to discern which particular editions of Virgil Denham knew and used (see EAV, pp. 30-1), Virgil is cited from the most recent Loeb edition: Eclogues, Georgics, Aeneid, ed. H. Rushton Fairclough, rev. G. P. Goold, 2 vols, Cambridge, 2014. The Loeb text has been checked against the seventeenthcentury Virgil vulgate. All glossing translations are my own unless otherwise stated.

2 R. Sowerby, The Augustan Art of Poetry: Augustan Translation of the Classics, Oxford, 2006, p. 2; The Complete Poetry of Robert Herrick, ed. T. Cain and R. Connolly, 2 vols, Oxford, 2013, I, pp. 221-2 (H673, 1. 12); The Works of John Dryden, ed. E. N. Hooker et al., 20 vols, Berkeley, 1956-2000, VIII, p. 100 .

3 Samuel Johnson's 'Life of Denham', in Lives of the Poets, ed. R. Lonsdale, 4 vols, Oxford, 2006, I, pp. 235-41 (238-9), was particularly significant in granting the poems this context; but Johnson himself was responding to the earlier comments by Herrick and Dryden, as well as, among others, Matthew Prior and Alexander Pope.

4 'To Sir Richard Fanshawe', 11. 15-16. For Coopers Hill and topographical poetry (and a survey of previous criticism on the topic), see D. Landry, 'Poems of Place', in The Oxford Handbook of English Poetry, 1660-1800, ed. J. Lynch, Oxford, 2016, pp. 335-55. For Denham and translation, see L. Venuti, The Translator's Invisibility: A History of Translation, London, 1995, pp. 44-65; T. Caldwell, 'John Dryden and John Denham', Texas Studies in Literature and Language, 46, 2004, pp. 49-72 (50-56); P. Davis, Translation and the Poet's Life: The Ethics of Translating in English Culture, 1646-1726, Oxford, 2008, pp. 19-39; Sowerby, Augustan Art (n. 2 above), pp. 94-113; EAV, pp. 11-13, 23-30, 118-30, 145-60.

5 This manuscript translation survives in a commonplace book that belonged to Lucy Hutchinson. J. de Groot, 'John Denham and Lucy Hutchinson's Commonplace Book', Studies in English Literature 1500-1900, 48, 2008, pp. 147-63 (154), discusses how the likeliest connection between Hutchinson and Denham came courtesy of Denham's status as a contemporary of Hutchinson's brother (Allen Apsley) at the inns of court in the early 1630s. The translation is thus thought to date from the 1630s, but it may not have been copied into Hutchinson's commonplace book until the early 1650s.
} 
Denham's political sympathies remains a contentious issue, but it is generally agreed that his poetry signals a loyalty to the royalist cause in a manner which allows censure as well as support of Charles I. ${ }^{6}$ The call for moderation and balance in Coopers Hill, particularly in the 'Thames couplets' 'B' Text, can be readily applied to a political standpoint, with the result that Denham's politics are often aligned with his aesthetic principles. ${ }^{7}$ Whilst such links did undoubtedly exist, they were not necessarily inextricable or simultaneous. Within the context of Denham's poetry, it is helpful to consider, in addition to an aesthetic Augustanism that emulates a Virgilian versification, a related but distinct political Augustanism motivated by a desire to emulate Virgil's presentation of heads of state. Here, too, there is no consensus on this topic, but for the present purposes it is important to register that Virgil's portrayal of such individuals, like Denham's portrayal of Charles, frequently involves criticism as well as praise. ${ }^{8}$

In this article I examine Denham's political and aesthetic Augustanism to outline the extensive cross-fertilization between Coopers Hill and his engagement with Virgil. Critics have already established points of contact between Coopers Hill and the Georgics, but here I focus on the Aeneid to suggest that Denham thought of his topographical poem within an epic, as well as georgic, framework. ${ }^{9}$ The most useful point of entry to discuss these issues is the passage in the Coopers Hill 'A' Text where 'our Charles' gives chase to and kills 'the royall Stagge'. ${ }^{10}$ This passage concludes with an account of how the stag:

tries his friends, amongst the lesser Heard,

Where he but lately was obey'd, and feard,

Safety he seekes, the heard unkindly wise,

\footnotetext{
${ }^{6}$ Connections between Denham's poetry and his politics are discussed in EH, pp. 165-256; J. Turner, The Politics of Landscape: Rural Scenery and Society in English Poetry 1630-1660, Oxford, 1979, pp. 58-60; R. Wilcher, The Writing of Royalism, 1628-1660, Cambridge, 2009, pp. 75-89; N. Smith, Literature and Revolution in England, 1640-1660, London, 1994, pp. 321-4; J. R. Curlin, “"Is There No Temperate Region...?": Coopers Hill and the Call for Moderation', in The English Civil Wars in the Literary Imagination, ed. C. J. Summers and T. Pebworth, London, 1999, pp. 119-29; A. B. Coiro, 'The Personal Rule of Poets', in The Oxford Handbook of Literature and the English Revolution, ed. L. L. Knoppers, Oxford, 2012, pp. 206-37 (209-15). J. Wallace, 'Coopers Hill: The Manifesto of Parliamentary Royalism, 1641', English Literary History, 41, 1974, pp. 494-540, discusses elements of Coopers Hill that criticize Charles whilst affirming Denham's support for the monarchy. A. Momeni, 'John Denham's The Sophy and Anglo-Persian Political Parallels', in Sir John Denham (1614/15-1669) Reassessed: The State's Poet, ed. P. Major, London, 2016 (henceforth SP), pp. 75-87, discusses moments in Denham's 1642 tragedy The Sophy that potentially offer veiled criticisms of Charles's policies.

7 The 'Thames couplets' are at Coopers Hill (1653/5), 11. 189-92. For the links between royalist aesthetics and politics, see Venuti, Translator's Invisibility (n. 4 above); L. Potter, Secret Rites and Secret Writing: Royalist Literature, 1641-1660, Cambridge, 1989, pp. 52-4; S. Zwicker, Lines of Authority: Politics and English Literary Culture, 1649-1689, London, 1993, pp. 1-2.

${ }^{8}$ For Virgil's ambivalent response to Augustus, and how it informs his characterization of Aeneas at key moments in the poem, see R. Thomas, Virgil and the Augustan Reception, Cambridge, 2001, pp. 53-4, and C. Kallendorf, The Other Virgil: 'Pessimistic' Readings of the Aeneid in Early Modern Culture, Oxford, 2007.

9 For Coopers Hill and georgic, see EH, pp. 9-10; Caldwell, 'John Denham and John Dryden' (n. 4 above), p. 58; Landry, 'Poems on Place' (n. 4 above), p. 337.

${ }^{10}$ Coopers Hill (1642), 11. 263, 265.
} 
Or chases him from thence, or from him flies,

Like a declining Statesman, left forlone

To his friends pitty, and pursuers scorne.

Wearied, forsaken, and pursude at last

All safety in despaire of safety plac't. ${ }^{11}$

Earl Wasserman's application of the 'declining Statesman' simile to the 1641 trial and execution of Thomas Wentworth, Earl of Strafford, Charles I's vice-regent in Ireland, has been widely accepted and has dominated subsequent interpretations of this passage. ${ }^{12}$ Brendan O Hehir even argues that Strafford's death was the main prompt for Denham to write Coopers Hill in the first instance. ${ }^{13}$ My analysis of this passage begins by considering how the stag-hunt episode incorporates political commentary through its use of Virgilian intertexts, particularly Aeneid II and VII, and how here and throughout the poem, Denham engages with Virgil via a number of techniques, which range from making largely de-contextualized local borrowings to suggesting parallels between Virgilian episodes and recent events in Denham's own society. I then discuss how Denham incorporated the 1640s and 1650s reception of Coopers Hill's political and aesthetic elements in the revised 'B' Text (1653/5) and in The Destruction of Troy.

The stag-hunt episode of Coopers Hill expands from forty lines in the 'A' Text to over eighty in the 'B' Text, and so represents the most substantial of Denham's revisions to the poem. For Wasserman, the expansion removes much of the earlier draft's initial balance and equipoise between the poem's individual episodes; but, as has subsequently been recognized, the change was motivated by Denham's desire to have the passage stand largely as a reference to Charles I's trial and execution. ${ }^{14}$ This revision has also been interpreted as an act of reclamation, not only from other re-purposings of the episode in poems by other royalists writing elegies on Charles (and other figures), but also from poets who had mined Coopers Hill for phrases and passages in panegyrics to Cromwell. ${ }^{15}$ Denham continued the practice of mourning Charles via a Virgilian proxy in The Destruction of Troy. Denham famously breaks off his translation at the moment of Priam's death:

\footnotetext{
11 Ibid., 11. 271-8.

12 See E. Wasserman, The Subtler Language: Critical Readings of Neoclassic and Romantic Poems, Baltimore, 1959, pp. 72-6. Wallace, 'Parliamentary Royalism', p. 519, offers an alternate reading in which the stag personifies arbitrary power, although this is challenged by Turner, The Politics of Landscape (n. 6 above), pp. 202-3.

13 Outlined in B. O Hehir, Harmony from Discords: A Life of Sir John Denham, Berkeley, 1968 (henceforth $H D$ ), p. 38.

${ }^{14}$ Wasserman, Subtler Language (n. 12 above), pp. 75-6; EH, 244-51. The revision in the application is also noted in Wilcher, Writing of Royalism (n. 6 above), pp. 339-40; Smith, Literature and Revolution (n. 6 above), p. 324; A. E. Carson, 'The Hunted Stag and the Beheaded King', Studies in English Literature 1500-1900, 45, 2005, pp. 537-56 (541-3); T. Raylor, 'The Hunting of the Stag: Denham, Davenant, and a Royalist Dispute over Poetry', in SP, pp. 143-60 (147).

15 See J. de Groot, Royalist Identities, Basingstoke, 2004, p. 194, and V. Anker, 'Sir John Denham the Political Satirist, 1642-46', in SP, pp. 88-105 (100) for discussion of the former; EH, pp. 284-8, and E. Holberton, Poetry and the Cromwellian Protectorate: Culture, Politics, and Institutions, Cambridge, 2008 , pp. 73-4, for examples of the latter.
} 
On the cold earth lies th' unregarded king,

A headless carcass, and a nameless thing. ${ }^{16}$

It has long been noted that the circumstances of Priam's death allow Denham to recall the death of Charles I in 1649, just as Virgil used Priam to recall the death of Pompey. ${ }^{17}$ The influence on Denham's Priam of the hunted stag from the Coopers Hill 'B' Text, has not, though, as far as I am aware, been acknowledged or considered. Timothy Raylor has discussed how the ' $\mathrm{B}$ ' Text is usually dated to 1655 but was actually first published in $1653 .{ }^{18}$ This earlier date nonetheless endorses the traditional account that Denham revised the 'A' Text of Coopers Hill and his manuscript Aeneid simultaneously in 1653 whilst at Wilton under the guardianship of the Earl of Pembroke, a composition process which suggests a particularly high degree of connection between these two editions.

Placing the revisions made to earlier versions of Coopers Hill and the Virgil translation for publication in the 1650s alongside each other bring out the other main focus of this article, which is Denham's use of the distinctive Virgilian strategy of the post eventum prophecy. This is the 'hindsight as foresight' that in 'Secondary Epic', his poem addressed to Virgil, Auden complains made 'no sense'. ${ }^{19}$ Where the post eventum prophecies in the Aeneid are given as formal prophetic utterances, either by the gods or by mortals granted godlike powers of foresight, Denham manipulates or withholds details of his texts' composition histories to intimate prescient qualities to passages that are framed as moments of retrospective narration (depictions of stag hunts in Windsor Forest during the 1630s, Aeneas' account to Dido of the Fall of Troy). The 1653 and 1655 'B' Text editions of Coopers Hill falsely present themselves as the lost original of the poem rather than as a substantial revision of the 1642 ' $A$ ' Text which responds to the events of 1649. The title-page of The Destruction of Troy is similarly (if less extensively) misleading when it states that it was 'Written in 1636'. It does not state that what is being published represents only a brief extract of a much larger translation project from the $1630 s^{20}$ Nor does it draw attention to how Denham had extensively

\footnotetext{
16 Destruction of Troy, 11. 548-9, translating Aeneid II.557-8.

17 Identified in G. Parry, 'A Troubled Arcadia', in Literature and the English Civil War, ed. T. Healy and J. Sawday, Cambridge, 1990, pp. 38-55 (47); Venuti, Translator's Invisibility (n. 4 above), pp. 53-4; Smith, Literature and Revolution (n. 6 above), pp. 229-30; D. Norbrook, Writing the English Republic: Poetry, Rhetoric, and Politics, 1627-1660, Cambridge, 1999, pp. 310-11; D. Landry, The Invention of the Countryside: Hunting, Walking and Ecology in English Literature, 1671-1831, Basingstoke, 2001, pp. 104-6; H. Power, 'Teares breake off my Verse: The Virgilian Incompleteness of Abraham Cowley's The Civil War', Translation and Literature, 16, 2007, pp. 141-59 (148); Davis, Translation and the Poet's Life (n. 4 above), p. 36; EAV, pp. 13, 144. The connection between Priam and Pompey has been made since at least the time of Lucan's Pharsalia (c. 61-5 AD). The intertextual relationship between Virgil's Priam and Lucan's Pompey is discussed in S. Hinds, Allusion and Intertext: The Dynamics of Appropriation in Roman Poetry, Cambridge, 1998, pp. 8-10.

18 T. Raylor, 'The “1653” Copy of Denham's Coopers Hill', Yale University Library Gazette, 71, 1997, pp. 130-39.

19 W. H. Auden, Collected Poems, London, 1993, pp. 598-600 (598).

20 T. Caldwell, 'Translation', in The Oxford Handbook of English Poetry, 1600-1800, ed. J. Lynch, Oxford, 2016, pp. 596-614 (599), says that The Destruction of Troy 'was published alone in 1636'; J. Stubbs, 'Denham as Cavalier', in SP, pp. 12-30 (29-30) gives a publication date of 1651. There is,
} 
revised the text for publication. Direct comparison between Denham's manuscript Virgil and The Destruction of Troy is possible for just over four hundred lines, and only around a third of this total (140 lines) is the same in both versions. ${ }^{21}$ The revisions are spread out across the translation rather than being concentrated in particular episodes or passages, which indicates a sustained and systematic overhaul of the text. This would help indicate that, even though any translation of Priam's death that was published in the 1650s would already resonate strongly with Charles I's execution regardless of its date of composition, Denham revised the lines in his translation to make the parallel even more pointed. There are, however, several lacunae in the manuscript Aeneid, including Aeneid II.491-585, a section which includes the death of Priam. ${ }^{22}$ The presence of this lacuna has ramifications for the identification of Charles I with Priam, since without the equivalent section of the manuscript translation it is not possible to ascertain if the couplet was genuinely the work of 1636, which acquired this new resonance after 1649, or if, as happened elsewhere in the poem, Denham revised his original version (or, possibly, translated the passage for the first time) in the early 1650 s in order to guarantee this political resonance. Robin Sowerby has persuasively argued that Denham's original translation was intended to be continuous and that the lacunae in the surviving manuscript represent gaps of transcription by copyists rather than of composition by Denham; it is therefore likely that Denham produced a version of the relevant passage in the 1630s. ${ }^{23}$ After the lacuna of Aeneid II.491-585, the manuscript contains a translation of all but the final thirteen lines of Aeneid II; so, at the very least, Denham was being selective in his publication of his earlier translation in order to make the parallels between the death of Priam and the death of Charles all the more apparent. ${ }^{24}$

\section{Footnote 20 continued}

however, no record of the translation being published, either with or without Denham's consent, in either of those years. ESTC (English Short Title Catalogue: http://estc.bl.uk) records a unique edition of Coopers Hill printed with The Destruction of Troy in the Codrington Library, All Souls, Oxford. It suggests a publication date of 1650, but this would pre-date Denham's revisions to both texts. It is more likely to have been published after the first edition of The Destruction of Troy had appeared in 1656.

21 Here I am indebted to, but extend, the account of the differences between the manuscript Virgil and The Destruction of Troy in EAV, pp. 118-30.

22 Sowerby notes additional lacunae at Aeneid II.370-419 and II.788-804. There is one further lacuna, as Denham's manuscript does not provide a translation of Aeneid II.314-35: at 11. 295-8 the transcription is continuous from Denham's translation of Aeneid II.313 - 'exoritur clamorque virum clangorque tubarum', 'The trumpets' dreadful sound/The louder groans of dying men confound' - and II.336: 'talibus Othryadae dictis et numine divum', 'Thus by the gods and by Othyrdes' words/Inspired'. The reference to 'Othyrdes' words' loses its meaning when the intervening section is removed, as the excised passage concerns Aeneas's encounter with Apollo's priest Panthus ('Othyrdes' is Panthus's patronym), who informs him that Troy's last night has come. The Destruction of Troy does contain a translation of this passage (11. 302-23).

23 See $E A V$, pp. 13-14.

24 The partial nature of The Destruction of Troy suggests affinities between Denham's translation and the tradition of the sortes Virgilianae, the practice of divination by randomly selecting a passage from Virgil. The most notorious post-classical example of this tradition concerns a consultation of the sortes in the 1640s which alighted on Dido's curse to Aeneas at Aeneid IV.615-20 and was held to touch upon the fate of Charles I. Several accounts of this consultation, involving a number of alternative dates and key individuals, were in circulation by the second half of the seventeenth century. My future research will 
As the prophetic elements of each poem are linked to its engagement with its political context, I contend that whilst Coopers Hill links politics and aesthetics from its first edition (an aspect of the poem which Denham subsequently expanded and revised in the ' $\mathrm{B}$ ' Text), Denham's first translation of Virgil is concerned primarily with an aesthetic Augustanism. It does not contain any noticeably political resonances; his Virgil only gains these qualities through later selective publication of the translation in the 1650s as The Destruction of Troy. Denham's manipulation of Coopers Hill and The Destruction of Troy in this way allows him to take advantage of anticipating events which have already occurred by the time of the poem's composition. If hindsight as foresight made no sense to Auden, it made perfect sense to Denham in the aftermath of the civil wars. The technique granted him the opportunity not only to 'foretell' the death of Charles I but also to downplay his earlier, inaccurate prophecy of a total royalist victory that occurs in the conclusion to the Coopers Hill 'A' Text and to substitute a retrospective prophecy of the arbitrary rule that emerged in the aftermath of the regicide. Such a technique shows Denham drawing on the prophecies within the Aeneid which 'predict' disaster instead of triumph; examples of the former are less common than the latter, but much more emotionally affecting. ${ }^{25}$ In The Destruction of Troy, retrospective prophecy grants Denham the opportunity to mourn Charles's death and intimate that the Stuart exile is final and irrevocable. But rather than using the translation as an opportunity to grant a greater sense of inevitability to the new republican status quo and so assuage his own sense of wounded honour, Denham instead uses Virgil to preserve his sense of unfulfilled duty to Charles and to the royalist cause, whilst also acknowledging Charles's faults. Paul Davis's reading of The Destruction of Troy as a work where Denham 'could avoid feeling at home in the republican present' is helpful in understanding this use of the text. ${ }^{26}$ The use of retrospective prophecy reduces, rather than augments, Denham's own sense of his agency as a loyal supporter of the Stuarts. From the 1650s there is a marked shift in emphasis in his poetry from criticism of others to self-criticism. The republication of Coopers Hill and The Destruction of Troy in 1668 in versions that are largely unchanged from those published in the Interregnum suggests that Denham continued to use these poems for this purpose after the Restoration.

\footnotetext{
Footnote 24 continued

investigate the provenance of these accounts in further detail and explore the possibility that this sortes consultation is (like The Destruction of Troy) another post eventum prophecy of Charles's death. It will also consider the influence of the accounts on the revisions Denham made to his own translation of Dido's curse when preparing sections of his manuscript Aeneid IV translation for publication as The Passion of Dido in his 1668 volume Poems and Translations.

25 The most celebrated incident of this type of prophecy occurs in the account of the premature death of Marcellus at Aeneid VI.860-86, which concludes the otherwise triumphalist parade of future Roman heroes.

26 Davis, Translation and the Poet's Life (n. 4 above), p. 30.
} 


\section{Coopers Hill 'A' Text (1642)}

Since Denham completed his manuscript Aeneid before starting work on Coopers $\mathrm{Hill}$, the initial direction of Virgilian influence in his own poetry is from translation to imitation. O Hehir has, in fact, identified several instances where the Coopers Hill 'A' Text draws on fairly close renderings from Denham's manuscript Aeneid; ${ }^{27}$ but there are other occasions in the poem, particularly in the stag hunt, where Denham allowed himself a greater latitude in his Virgilian borrowings. His 'All safety in despaire of safety plac't', for example, echoes the cold comfort Aeneas offers to his men on the last night of Troy: 'una salus victis nullam sperare salutem' ('there is one salvation available to the conquered, and that is not to hope for any salvation'), which he had rendered in the 1636 manuscript as 'this one/Relief the vanquished have to hope for none'. ${ }^{28}$ The 1676 Latin translation of the poem by Moses Pengry recognizes this parallel, as it directly borrows from the original text to translate the line as 'Hanc unam cernit, nullam sperare, salutem' ('he sees this one salvation, and that is not to hope for any'). ${ }^{29}$ The manuscript translation offers a comprehensive rendering, but it does not acknowledge the original play on Virgil's 'salus' in the way that 'All safety in despaire of safety plac't' does. This picks up on the type of compact but sophisticated rhetoric that clearly appealed to Denham, as evidenced by lines earlier in the poem such as 'Those made not Poets, but the Poets those' and 'Some to undoe, and some to be undone' ${ }^{30}$ Such a difference of approach informs Dryden's comment that, in the celebrated preface to The Destruction of Troy, Denham 'advis'd more Liberty than he took himself' in the actual translation. ${ }^{31}$ As The Destruction of Troy retained 'this one/Relief the vanquished have, to hope for none' from the manuscript translation, it indicates how approaches to representing the spirit of the author can differ even with the work of one translator.

In this particular instance from Coopers Hill Denham's allusive practice is still likely founded on an aesthetic Augustanism that invokes the content of Virgil's line whilst downplaying its immediate context (except perhaps its emotional impact), in the manner of the borrowings from his 1636 manuscript translation identified by $\mathrm{O}$ Hehir. It is not necessary to have produced a translation of Aeneid II to be familiar with the line. It offers the type of easily-detachable maxim that is suitable for

\footnotetext{
${ }^{27}$ These occur at Coopers Hill (1642), 11. 10-11 (cf. Denham, Aeneid VI.16-17); 11. 189-90 (cf. Denham, Aeneid V.827-9); 11. 253-4 (cf. Denham, Aeneid VI.660).

28 Virgil, Aeneid II.354; Denham, Aeneid II.314-15.

${ }^{29}$ Pengry, Coopers Hill, 1. 284. Quotations from Pengry are from the edition printed in EH, pp. 257-75. Pengry translates the ' $\mathrm{B}$ ' Text, rather than the ' $\mathrm{A}$ ' Text, but this line is the same in both editions.

${ }^{30}$ Coopers Hill (1642), 11. 4, 36.

${ }^{31}$ Dryden, Works (n. 2 above), I, p. 117. Davis, Translation and the Poet's Life (n. 4 above), pp. 29-30 picks up on Dryden's comment to discuss how The Destruction of Troy is not as free a translation as it is often made out to be, and could even be a partial refutation of the approach that Denham articulated in the preface and in his commendatory poem to Fanshawe. By contrast, EAV, p. 129 contends there is no significant difference between Denham's translation theory and his practice in The Destruction of Troy. Within this context it is noticeable that the translation of 'una salus victis nullam sperare salutem' in the most recent Loeb edition, which generally seeks to provide as close and 'unpoetic' translation of the original as possible, is 'One chance the vanquished have, to hope for none' (I, p. 341), which is clearly indebted to Denham's rendering in the manuscript Aeneid and The Destruction of Troy.
} 
commonplacing, and the phrase occurs in a number of early modern texts, including a collection of classical sententiae that appeared the year after the 'A' Text was first published. ${ }^{32}$ Its appeal for Denham was more the result of its linguistic properties than its ability to offer a political parallel.

The political charge of the stag-hunt occurs from placing the episode alongside a different moment of the Aeneid. Some of the elegies that were written in the immediate aftermath of Strafford's death present it as a noble self-sacrifice that would prevent civil war. Denham's own elegy for Strafford, however, adopts an equivocal position on the ramifications of his death, and by the time he was drafting Coopers Hill it was apparent that the execution was a key factor in provoking armed conflict. ${ }^{33}$ This passage of Coopers Hill is, therefore, likely influenced by Aeneid VII, in which the hunting and killing of a stag precipitates war between Turnus's Rutulians and Aeneas's Trojans. As both sides had Italian allies, and Aeneas claimed Italy as his ancestral homeland, the conflict is consequently simultaneously coded as both a foreign and a civil war. The Fury Allecto, acting on Juno's order to foment discord in Latium, has made the hounds that belong to Aeneas's son Ascanius (also known as Iulus) set on a deer during a hunting expedition. Allecto then guides Ascanius's aim as he shoots at the deer:

Hunc procul errantem rabidae venantis Iuli commovere canes, fluvio cum forte secundo deflueret ripaque aestus viridante levaret. ipse etiam eximiae laudis succensus amore Ascanius curvo derexit spicula cornu; nec dextrae erranti deus afuit, actaque multo perque uterum sonitu perque ilia venit harundo. saucius at quadripes nota intra tecta refugit successitque gemens stabulis, questuque cruentus atque imploranti similis tectum omne replebat. ${ }^{34}$

(When [the stag] was wandering far off, the maddened dogs of Iulus set on it, as it happened to swim downstream and cooled off the heat on a grassy bank. Ascanius himself, struck with a desire for high praise, directed an arrow from his curved bow, the goddess [Allecto] made his aim secure, and the arrow, released with a great sound, pierced both belly and bowels. But the wounded animal fled to its familiar abode, and, moaning, made for its stable, and, bloodstained and groaning, filled the whole house in the manner of someone asking for help.)

Unbeknown to Ascanius, the deer he has shot is not, unlike other deer in the Aeneid, a wild animal and a potential source of food or sport that can be killed without remorse. It is a pet belonging to Sylvia, the daughter of King Latinus's chief herdsman, Tyrrhus. Her calls for help summon her fellow Italians, who arm

\footnotetext{
32 Analecta Poetica Graca Latina, Oxford, 1643, p. 29.

33 See Wilcher, Writing of Royalism (n. 6 above), pp. 55-66.

34 Virgil, Aeneid VII.493-502.
} 
themselves and make for Ascanius. The Trojans come to Ascanius's aid, which prompts an outbreak of fighting between these two peoples. This causes the death of an Italian at the hands of a Trojan, and, later, the formal, ritual declaration of war signalled by the opening of the gates to the Temple of Janus. ${ }^{35}$

The parallel to this passage in Coopers Hill is, then, primarily situational rather than linguistic. Denham makes no direct reference to this event. This may be because the episode itself is a somewhat extended one and does not contain any particularly celebrated or imitated lines of verse. What Denham is invoking is the episode as a whole, rather than its text. This context allows him to make a fairly wide-ranging application which grants an added pathos to the stag/Strafford. By killing this figure, Charles, like Ascanius, makes the outbreak of civil war inevitable. This interpretation would have been particularly resonant when Coopers Hill was published in August 1642, a week prior to Charles I raising his standard at Nottingham Castle, the act which is traditionally held to symbolize the outbreak of armed conflict.

The Virgilian intertexts in Coopers Hill raise questions of who is ultimately responsible for Strafford's death. They possibly indicate that Denham sought to incorporate the fatalism that is present in much of the Aeneid. Troy has to fall, so there is no hope of safety for the Trojans, and Ascanius and his dogs are not responsible for their actions; they are, like the Greeks of Aeneid II, vessels for a higher power. This would help give the impression that the death of the stag - and so, within the political application, Strafford - and the outbreak of civil war was pre-destined and inevitable. Fate could potentially have been delayed, but not avoided altogether. Such a reading could help assuage Charles's sense of agency regarding Strafford's death. Whilst he did so only with extreme reluctance, it was nonetheless Charles who ordered Strafford's execution. ${ }^{36}$ Denham reflects historical reality by directly naming the stag's killer as Charles I:

Till Charles from his unerring hand lets flie

A mortall shaft, then glad, and proud to dye

By such a wound he fals, the Chrystall flood

Dying he dyes, and purples with his blood... 37

The comparison draws on long-standing associations between deer and royalty, since deer in the royal forests could only be hunted by the monarch. ${ }^{38}$ Its final line offers a similar formal patterning identified to his earlier imitation of 'una salus victis nullam sperare salutem'. Whilst it owes something to the Virgilian trope of aestheticizing a body at the moment of death it ultimately seems closer to the type of highly patterned rhetorical 'turn' that is more usually associated with an Ovidian

\footnotetext{
35 See Virgil, Aeneid VII.503-640.

36 Discussed in Wilcher, Writing of Royalism (n. 6 above), p. 61.

37 Coopers Hill (1642), 11. 297-300.

38 There is also perhaps a further reference here to the 'forest fines' which Charles had re-instituted during the 1630 s as a means of raising revenue without having to recall Parliament. For details, see G. Hammersley, 'The Revival of the Forest Laws under Charles I', History, 45, 1960, pp. 85-102.
} 
than a Virgilian poetics. ${ }^{39}$ Given the Virgilian presence in the poem Denham's use of 'unerring hand' may be intended to contrast with the hand of Ascanius that requires steadying by Allecto in order to bring down the stag. If this is the case, unlike Virgil's Ascanius, Denham's Charles is his own agent. Far from alleviating Charles's responsibility for Strafford's death, this parallel with Ascanius and the stag helps to affirm it, since it insinuates that no one was directing Charles's hand other than Charles himself.

The desire to criticize as well as support Charles also informs the prophecy which ends the poem. ${ }^{40}$ Denham imagines an imminent re-assertion of royal authority, which he likens to a river bursting its banks. His choice of comparison again suggests disquiet rather than vindication. Robert Wilcher has suggested that Denham's preferred mode of governance was a balance of power between sovereign and Parliament defined as 'constitutional royalism'. ${ }^{41}$ The conclusion to Coopers Hill consequently expresses unease at the prospect of royal authority re-asserting itself so thoroughly over Parliament that there is the risk of the monarchy degenerating into a tyranny. Using an overflowing river to discuss the nature of overreaching political power was a long-standing metaphorical commonplace, but the account could also echo Sibyl's account of the Tiber from Aeneid VI. Virgil's Sibyl has the gift of prophecy and foretells the war which Ascanius's killing of Sylvia's stag precipitates:

bella, horrida bella

et Thybrim multo spumantem sanguine cerno. ${ }^{42}$

(I see wars, horrible wars, and the Tiber foaming with much blood.)

Even at this initial stage in the conflict and in the complex life of Coopers Hill Denham is beginning to align his poetry with disquieting prophecy regarding the death of Strafford and the constitutional crisis it provoked. ${ }^{43}$

From Denham's royalist perspective, the execution of Strafford did unleash tyrannical rule, but the tyranny in question was parliamentary and military rather than monarchical. There is, of course, nothing in the Coopers Hill 'A' Text which intimates that Strafford's death will set in motion a chain of events leading to the abolition of the monarchy, but its concluding account of overwhelming royal triumph would have already begun to ring hollow when the poem was reissued in 1643, and the discrepancy between prophecy and reality would have been all the more marked for readers of the '1650' edition. Thomason struck through the year on his copy's title-page, replaced it with ' 1649 ' and added the date 'Jan 21.', which

\footnotetext{
39 C. Martindale, 'Shakespeare and Virgil', in Shakespeare and the Classics, ed. C. Martindale and A. B. Taylor, Cambridge, 2004, pp. 89-106 (98) discusses the Virgilian trope of aestheticization in relation to the death of Euryalus at Aeneid IX.433-7. Dryden refers to Denham's 'turns' in Works (n. 2 above), IV, p. 84 .

40 Coopers Hill (1642), 11. 329-54.

41 See Wilcher, Writing of Royalism (n. 6 above), pp. 67-120, which also includes discussion of Denham's contemporary occasional poetry, as well as the Coopers Hill 'A' Text, within this context.

42 Virgil, Aeneid VI.86-7.

43 For further analysis of the 'A' Text conclusion in this context, see Norbrook, English Republic (n. 17 above), pp. 78-9.
} 
indicates that it appeared only ten days prior to Charles's execution. ${ }^{44}$ This event itself may explain why the year of publication is given as 1650 . Even if it was wishful thinking, this later edition of Coopers Hill tries to predict that the death of Charles would prompt a royalist backlash of a type that was not seen in 1642. The prophecy would consequently be delayed, but not undermined. A royal tyranny would, for Denham, seem preferable to its republican counterpart.

By the time Denham revised Coopers Hill and published the 'B' Text, however, such a backlash had failed to materialize. This edition nonetheless sought to reassert the poem's status as a work of political prophecy, which it does by altering its conclusion to offer commentary from a royalist perspective on the arbitrary rule that followed the regicide. ${ }^{45}$ Lois Potter has discussed how "many of the so-called "ancient prophecies" published in the seventeenth century... attracted attention only after events had seemed to prove them right'. ${ }^{46}$ By suggesting that the 'B' Text represents the original draft of the poem, Denham ensures that this was the case in his own poem through his intimation that the passage in question is a prophecy of an event which has come to pass between composition and publication. The same desire informs Denham's revisions to the stag-hunt passage in the light of Charles I's execution. Before examining this aspect of his revised Coopers Hill, however, it is first necessary to consider how the ' $\mathrm{B}$ ' Text responds to the reception of the 'A' Text, and how the stag-hunt had been co-opted as a site of royalist commemoration by other writers between 1642 and 1653 .

\section{Wounded Deer and Royalist Elegy}

Coopers Hill achieved a high circulation and reputation almost immediately, especially in the royalist wartime capital of Oxford, where the 1643 edition was published. Several Oxford-based writers drew on the poem for their own compositions, and the stag-hunt passage was adapted and applied to the deaths of Stuart loyalists other than Strafford relatively quickly. Denham himself first used the stag-hunt passage for the elegy of another individual in his contribution to Lachrymae Musarum. This volume was a collection officially dedicated to the death of Henry Hastings in June 1649, but many of its contributors, including Denham, used this occasion to mourn Charles's execution. Denham calls Charles 'the Leader of the Herd' who fell 'A Sacrifice to quench the raging thirst/Of inflam'd Vengeance for past Crimes'. ${ }^{47}$ The 'past Crimes' are presumably, in this context, a reference to Strafford's death. Even whilst acting as an elegy to Charles, this poem, like the 'A' Text of Coopers Hill, thus incorporates criticism of his actions.

Several poems written soon after 1649 also contain stag hunts that have been interpreted as reflections on Charles's death, the best known of which is Marvell's

\footnotetext{
44 This draws on information about this edition in ESTC.

45 Coopers Hill (1653/5), 11. 343-58.

46 Potter, Secret Rites (n. 7 above), pp. 149-50.

47 'An Elegy Upon the Death of the Lord Hastings', 11. 27-9.
} 
'A Nymph Complaining for the Death of her Fawn' ${ }^{48}$ Nigel Smith notes how the Aeneid VII episode, along with other accounts of wounded deer from classical literature, "exist as significant, threatening shadowy presences behind the poem, relating to its own civil war context'. ${ }^{49}$ Whilst Marvell's 'Nymph' is connected to this particular Virgilian moment, the Aeneid forms part of a highly complex and ambiguous network of associations that are at work in the poem, not least because Marvell's own political affinities cannot be delineated with the same confidence as Denham's, or indeed other writers who used Coopers Hill in their own works during the Interregnum. A firmer connection exists between Coopers Hill and other contemporary texts that contain descriptions of wounded or hunted deer which are applied to Charles's imprisonment, trial and execution. These include Hester Pulter's 'The invitation into the Countrey', 'Vpon the Death of my deare and lovely Daughter Iane Pulter' and several of her emblem poems; ${ }^{50}$ the hunting episode in I.ii of William Davenant's Gondibert (1650); ${ }^{51}$ William Denny's Pelecenicidium (1653); ${ }^{52}$ and Margaret Cavendish's 'The Hunting of a Stag' (1653). ${ }^{53}$ Although some of these texts were published in the same year the ' $\mathrm{B}$ ' Text of Coopers Hill came out, their dates of composition are usually placed around 1650-52. Although it is possible they were responding to Denham's own use of the 'stag-as-Charles' trope in Lachrymae Musarum, it is more probable, given its greater popularity, that these poets were adapting the 'A' Text 'stag-as-Strafford' application.

The majority of these writers moved in overlapping royalist circles: Niall Allsop discusses Denham's likely involvement in annotating a copy of Gondibert (now in the National Library of Scotland) and relates these annotations to the anti-Davenant satires that circulated in the 1650 s, with which Denham and, to a much lesser extent, Pulter, are known to have been involved. ${ }^{54}$ Sarah Ross argues for a connection between Pulter's 'Vpon the Death' and Marvell's 'Nymph', ${ }^{55}$ but it is likely the use

\footnotetext{
48 This paragraph draws on, and extends, information presented in Carson, 'Hunted Stag' (n. 14 above). Carson mentions the Aeneid VII stag-hunt episode in passing, but does not link it to its connections to civil war.

49 The Poems of Andrew Marvell, ed. N. Smith, Harlow, 2007, p. 65.

50 Discussed in S. Ross, Women, Poetry, and Politics in Seventeenth Century Britain, Oxford, 2015, pp. 140-2, 146-52, 164-6.

51 Sir William Davenant's Gondibert, ed. D. F. Gladish, Oxford, 1971, p. 295 also notes the episode's parallel with Aeneid VII and with the Coopers Hill stag-hunt.

52 Mentioned in Potter, Secret Rites (n. 7 above), pp. 192-3.

53 Poems, and Fancies: Written by the Right Honourable, the Lady Margaret Marchiones Newcastle, London, 1653, pp. 113-16.

54 See N. Allsop, “Lett none our Lombard author rudely blame for's righteous paine": An Annotated Copy of Sir William Davenant's Gondibert (1651)', The Library: Transactions of the Bibliographical Society, $7^{\text {th }}$ series, 16, 2015, pp. 24-50. This augments the account of the strained relationship (pre- and post-Restoration) between Denham and Davenant outlined in M. Nevitt, 'Restoration Theatre and Interregnum Royalism: The Cavalier Rivalry of John Denham and William Davenant', in SP, pp. 52-74, and Raylor, 'Hunting of the Stag' (n. 14 above). Raylor uses the stag-hunt passages of Coopers Hill and Gondibert as a means of distinguishing the differing poetic aesthetics of the two men, rather than on their shared status as royal elegies. Ross, Women, Poetry, Politics (n. 50 above), pp. 172-3 discusses Pulter's poem on Davenant.

55 Ross, Women, Poetry, Politics (n. 50 above), pp. 146-52.
} 
of deer in her other poetry was influenced by Davenant. Immediately after describing the stag's mortal arrow-wound in Gondibert, Davenant refers to how 'sharp Dittany now vainly grew' in the forest. ${ }^{56}$ Dittany was supposed to make arrows fall out of animals' bodies and Virgil draws on this tradition by having Aeneas's arrow-wound cured by the application of dittany in Aeneid XII. ${ }^{57}$ Davenant's reference to the plant may inspire the presence of dittany in one of Pulter's emblem poems that feature Charles as a deer. ${ }^{58}$ Such a high degree of connection means that it is not possible to trace a distinct line of influence in terms of the 'stag-as-Charles' trope. These poets could also have drawn on the Aeneid independently of each other, but it is more likely that they approached Virgil through Coopers Hill.

The major difference between the 'A' Text of Coopers Hill and Denham's poem on Hastings (as well as the other elegies discussed) is that changing the application to the killed stag to refer to the death of Charles reverses the narrative of its Virgilian intertext and of the civil conflict itself: the death of the stag is a concluding, rather than an opening, act of war. The royalist experiences of the midseventeenth century did, however, reverse the narrative of the Aeneid. They fought a civil war (as Aeneas does in Aeneid VII-XII), but they emerged as the losing party in a conflict which subsequently forced them into exile (as Aeneas does in Aeneid IVI). This broad truth, however, did not necessarily correlate with individual circumstances, and various royalists, including Denham, experienced periods of exile during the 1640s and 1650s. Consequently, the royalist experiences of war and displacement do not neatly map onto the narrative of the Trojans in the Aeneid. In addition, Denham's contribution to Lachrymae Musarum (and later in the Coopers Hill ' $\mathrm{B}$ ' Text) could well re-purpose the passage to reflect on the fact that the execution of Charles I did not so much conclude the civil war but provoke a new phase of it, which involved the re-conquest of Ireland and Scotland by the Parliamentary army in 1649-50, and did not conclude until Cromwell's victory at Worcester in 1651. Just as Aeneas fought two conflicts in succession, one in his birth land of Troy and another in his ancestral land of Italy, so too did the royalists find themselves involved in a war with two distinct phases, the first lasting from the early 1640 s to 1646 , the second from 1648 to 1651 . Between 1649 and 1651 royalists and non-royalists alike would have reason to consider Charles's execution as a seismic, but not conclusive, act.

\footnotetext{
56 Gondibert I.ii.55.4.

57 Virgil, Aeneid XII.411-19. Gondibert, p. 296 notes the Virgilian associations of dittany. Ross, Women, Poetry, Politics (n. 50 above), pp. 164-5 focuses on other (post-Virgilian) references to the plant. R. Tarrant, Virgil: Aeneid Book XII, Cambridge, 2012, p. 197, draws a parallel between the Aeneid XII passage and the celebrated simile at Aeneid IV.69-73 where Dido is compared to a wounded deer. The melancholy and pathos in Denham's account of the stag-hunt in Coopers Hill may also be generally informed by the Aeneid IV simile, as well as the passage on Sylvia's stag in Aeneid VII.

58 Whilst Pulter likely draws on Denham, Marvell and Davenant, there is nothing to indicate that they were familiar with her writing.
} 
Tracing the influence of Coopers Hill is more complicated with regard to a poem by Henry King which also compares Charles to a hunted deer. ${ }^{59}$ The poem claims to have been written in the immediate aftermath of Charles's execution, but it was not published until $1660 .^{60}$ In the case of King's poem, however, the stag reference comes immediately after an account of Strafford's death, so it is more likely that he was drawing on the Coopers Hill 'A' Text. As a result, it seems likely that King's poem was written early in the Interregnum.

1660 saw the publication of number of elegies on Charles I, some of which, such as John Quarles's Regale lectum misera, were genuine reissues of poems that had first been published in 1649, but others, such as Anthony Sadler's The loyall Mourner, may only have falsely claimed this status. ${ }^{61}$ The title-page claims that the poem is 'Shewing the Murdering of King Charles the First' and 'Fore-Shewing the Restoring of King Charles the Second. In an Elegy Written and presented unto many, in that fatall Year 1648. Now Printed And Presented to His Majesty in this signal Year 1660'. Sadler's 'prophetique elegy', like the poems by Marvell, Davenant, Pulter, Cavendish and King, compares the executed Charles to a hunted deer. Charles is:

\section{this Royall HART;}

which was so Foully Hunted, and became,

so great a Prey; to such as scorn'd the GAME. ${ }^{62}$

Unlike these other poems, it potentially conceals or gives incorrect information regarding its date of composition, thus allowing Sadler to use hindsight as foresight. Such a strategy is paralleled in the 'B' Text of Coopers Hill, and not only with regard to Sadler's description of Charles as the 'Royall HART'. On its first publication in 1653 the title-page claimed that Coopers Hill was 'Written in the yeare 1640' and that the edition was 'Now Printed from a Perfect Copy; And a Corrected Impression'. O Hehir has established, however, that Denham not only thoroughly revised Coopers Hill prior to its republication, but that he also saw the ' $\mathrm{B}$ ' Text editions and several earlier printings of the ' $\mathrm{A}$ ' Text through the press, so the claims to unique authenticity that the ' $\mathrm{B}$ ' Text makes are false. ${ }^{63}$ The title-page statement (which also appeared on the 1655 reprint), combined with the 'stag-asCharles' application, allows Denham to write his own 'prophetique elegy'.

\footnotetext{
${ }^{59}$ See H. King, An Elegy Upon the Most Incomparable K. Charls the I. Persecuted by Two Implacable Factions, Imprisoned by the One, and Murthered by the Other, January 30th 1648, London, 1660, p. 7.

${ }^{60}$ King's Elegy borrows a few local details from A Groane at the Funerall of that incomparable and Glorious Monarch, Charles the First, King of Great Brittaine, France, and Ireland \&c. On whose Sacred Person was acted that execrable, horrid, and prodigious Murther, by a trayterous Crew, and bloudy Combination at Westminster, January the 30. 1648, an elegy on Charles I that he did publish in 1649, but they remain essentially separate poems.

61 This possibility is discussed with regard to other texts in Potter, Secret Rites (n. 7 above), p. 184.

62 A. Sadler, The loyall Mourner, London, 1660, p. 6.

63 EH, p. 138.
} 


\section{Coopers Hill 'B' Text (1653/5)}

The paratextual material that was added to the re-issued ' $\mathrm{B}$ ' Text of 1655 elaborates the title-page claim to its status as a corrected impression from a perfect copy, and in doing so helps seed the parallel between the killed stag and Charles I. The 'Note to the Reader', whose author is identified only as 'J. B.', ${ }^{64}$ grants the passage special attention by referring to 'the excellent Allegory of the Royall Stag'. The use of 'Royall' here, even though (as O Hehir has observed) the 'B' Text Coopers Hill does not call the stag 'royall' at any point - as had been the case in the ' $A$ ' Text - steers readers towards making a political application in the passage. ${ }^{65}$ Whilst the stag of the ' $B$ ' Text primarily refers to Charles I, Denham does not, however, entirely banish the earlier parallel with Strafford. Charles ends up in this edition as both perpetrator and victim. At this moment Denham may be recalling his account of Sinon in Aeneid II who is 'At once the taker and at once the prey'. ${ }^{66}$ The circularity of this phrase fits the connections that were frequently drawn between these two executions at the time, including by Charles himself. O Hehir notes that Charles 'regarded his acquiescence in the death of Strafford as the moral origin of his own calamity', and publicly expressed his sense of culpability in this event whilst he himself was on the scaffold. ${ }^{67}$ Denham also added a couplet to the 'B' Text version of the 'declining Statesman' simile to remind readers that Charles's fate mirrored Strafford's. The deer, abandoned by his friends, 'With shame remembers, while himselfe was one/ Of the same heard, himselfe the same had done' ${ }^{68}$ Here, and in the reference to overmighty kings that is given new prominence in the reworked conclusion, 'Thus Kings, by grasping more than they could hold,/First made their Subjects by oppression bold', Denham preserves the note of censure found in the 'A' Text. ${ }^{69}$ The prophecy of regicide and seemingly total royalist defeat which the ' $B$ ' Text substitutes for the ' $A$ ' Text conclusion of royal power reasserting itself also indicates that Denham still glances at the role Charles played in his own downfall even when mourning him.

Despite this note of criticism, O Hehir has drawn attention to how many of Denham's additions serve to increase the emotional affect of the passage and elicit greater sympathy for the fallen stag, and links this increase to the altered political context. ${ }^{70}$ Lamentation, rather than censure, remains the primary intention of the episode, which suggests further affinities with the stag-hunt from

\footnotetext{
${ }^{64}$ P. W. Thomas, Sir John Berkenhead 1617-1679: A Royalist Career in Politics and Polemics, Oxford, 1969, pp. 192-3 suggests that 'J. B.' was the royalist satirist and newsbook writer John Berkenhead. N. McDowell, Poetry and Allegiance in the English Civil Wars, Oxford, 2008, p. 169, strengthens the identification.

65 EH, p. 138.

66 Denham, Aeneid II.56; Destruction of Troy 1. 58. Pope later imitated this phrase in Windsor Forest, where another king who was killed, William Rufus, is called 'At once the chaser, and at once the prey' (1. 82). The death of Rufus during a deer-hunt also suggests a parallel with the stag-hunt passage of Coopers Hill. Pope's recall of The Destruction of Troy in this line indicates the collapsed boundaries in his literary memory between Denham's two major poems.

67 EH, p. 155.

68 Coopers Hill (1653/5), 11. 275-6.

69 Ibid., 11. 343-4.

${ }^{70}$ EH, p. 35. Carson, 'Hunted Stag' (n. 14 above), pp. 538-9, 540-43 builds on O Hehir's reading.
} 
Aeneid VII. ${ }^{71}$ Virgil depicts the wounded stag in an especially tender manner, to the extent that the stag is presented in essentially human terms; the stag weeps as it dies and its suffering provokes tears in others. ${ }^{72}$ Sylvia mourns the stag as though he were a sibling rather than a pet. If Denham blurs the boundaries between the human and the animal in his own hunted stag, doing so complements Virgil's own approach in this particular episode.

Pengry's Latin translation of the poem also indicates the continued significance of Aeneid VII to the Coopers Hill 'B' Text. He translates a line that is added to this edition where the stag 'All instruments, all Arts of ruine met' as 'artes mille nocendi' ('a thousand ways of doing harm'). ${ }^{73}$ This is likely inspired by Juno's account of Allecto's abilities: 'tibi nomina mille,/mille nocendi artes' ('you have a thousand names, a thousand means of doing harm'). ${ }^{74}$ Whilst this may just be a commonplace in the manner of 'una salus victis nullam sperare salutem' discussed above, Virgil's line occurs immediately prior to the episode of Ascanius and the stag-hunt, and, as already outlined, it is Allecto who incites rage in Ascanius's hunting hounds and guides his arrow. Whilst it is possible that Denham had this phrase in his mind when writing 'all Arts of ruine met', the connection is not quite as overt as in other incidents of Virgilian lines in the ' $A$ ' and ' $B$ ' Texts. In this respect, Pengry's translation is more overtly Virgilian than Denham's original poem.

The 1655 ' $\mathrm{B}$ ' Text downplays its status as a retrospective elegy by seeking to override the previous versions that had previously been published, including the 1653 edition. The 'Note to the Reader' begins:

You have seen this Poem often, and yet never: for, though there have been Five Impressions, this now in your hand is the onely true Copie. Those former were all but meer Repetitions of the same false Transcript, which stole into Print by the Author's long absence from this Great Town. I had not patience (having read the Originall) to see so Noble a Peece so Savagely handled: Therefore I obtained from the Author's owne papers this perfect Edition. ${ }^{75}$

The Note also singles out 'That excellent Allegory of the Royall Stag' for attention, as, rather than calling it a redrafted passage, 'J. B.' states, in language that itself recalls a beheading, that it was 'among others... lop't off by the Transcriber'. ${ }^{76}$ Ann Baynes Coiro draws parallels between the ' $\mathrm{B}$ ' Text's implicit presentation of itself as a prophetic text and Milton's republication of Lycidas in his 1645 Poems. $^{77}$

\footnotetext{
71 Raylor, 'Hunting of the Stag' (n. 14 above), pp. 149-50 suggests Gratius Faliscus's Cynegeticon as an alternative classical influence on the ' $\mathrm{B}$ ' Text stag-hunt.

72 See Aeneid 7, ed. Nicholas Horsfall, Leiden, 2000, pp. 319-54.

73 Coopers Hill (1653/5), 1. 258; Pengry, Coopers Hill, 1. 252.

74 Virgil, Aeneid VII.337-8.

75 Coopers Hill (1655), sig. A2r.

76 Denham, Coopers Hill (1655), sigs $\mathrm{A} 2^{\mathrm{r}}-\mathrm{B}^{\mathrm{v}}$. The use of such language supports the claim by Thomas, Royalist Career (n. 64 above), pp. 192-3, that the note has a satirical streak in it.

77 Outlined in Coiro, 'Personal Rule' (n. 6 above), p. 210. Coiro does not capitalize on the fact that the two texts shared a publisher, Humphrey Moseley, who had also published the 1649 and 1653 editions of Coopers Hill. Potter, Secret Rites (n. 7 above), pp. 20-22, 162-3, discusses how Moseley's staunch
} 
Milton added a headnote to Lycidas in this volume that looks back to the poem's first publication in 1637 :

In this monody the author bewails a learned friend, unfortunately drowned in his passage from Chester on the Irish Seas, 1637. And by occasion foretells the ruin of our corrupted clergy then in their height. ${ }^{78}$

For Coiro, this headnote 'inserts a new political interpretation of his pastoral', and she maintains that 'Coopers Hill's ongoing negotiation with changing historical circumstances far exceeds Milton's 1645 Lycidas in scale and ambition'. 79 This interpretation overlooks the fact that the headnote is the only text that is added to the 1637 Lycidas. $^{80}$ Milton draws on classical (and, just as significantly, biblical) traditions concerning the poet as seer, but also grants himself the additional kudos of intimating that Lycidas had not just foreseen the ruin of the corrupted Laudian clergy, but had helped to bring it about. ${ }^{81}$ Republishing the poem in 1645 , the year of Laud's execution, could also assist this interpretation. ${ }^{82}$ Back-dating the composition of the Coopers Hill 'B' Text allowed Denham and the publisher to introduce a prophetic aspect that would have been impressive enough in the case of Strafford, but would be even more so regarding the execution of Charles I. However, the ' $\mathrm{B}$ ' Text can only achieve this quality and present a greater sense of scale by exploiting the benefit of hindsight and presenting a poem that was revised in the 1650s as the work of the early 1640s; the republished Lycidas does not, by contrast, contain a false date of composition or present a revised text as an original draft. ${ }^{83}$ Milton consequently grants himself a greater sense of agency regarding poetic foretelling than is present in Coopers Hill, which is noticeably more elegiac, mournful and, in the re-worked conclusion, even apocalyptic. The greater foreknowledge that is made available by retrospective prophecy reduces Denham's sense of authority over the events that his poetry describes. This factor informs Denham's The Destruction of Troy, to which I now turn. As well as drawing textually on Coopers Hill at points, the translation also gives a misleading account of its origin. ${ }^{84}$

Footnote 77 continued

royalism informed his publications throughout the civil war and Interregnum, including Milton's 1645 Poems.

78 Milton: Complete Shorter Poems, ed. J. Carey, 2nd edn, Harlow, 1997, p. 243.

79 Coiro, 'Personal Rule' (n. 6 above), p. 210.

${ }^{80}$ Milton: Shorter Poems (n. 78 above), pp. 238-9 charts the other (almost exclusively orthographical) differences between the 1637 and 1645 editions.

81 In relation to this approach, Potter, Secret Rites (n. 7 above), pp. 162-3 argues that the added headnote is Milton's response to Moseley shaping the volume according to his royalist principles.

82 Laud was executed in January 1645, and, whilst dated 1645, Milton's Poems potentially did not appear until the start of the following year.

83 Virgilian retrospective prophecy does not play a role in Lycidas, but it is a key feature of Paradise Lost, as K. W. Gransden discusses in 'Aeneid and Paradise Lost', in Virgil and his Influence, ed. C. Martindale, Bristol, 1984, pp. 95-116 (105-6; 112-16).

84 For an instance in The Destruction of Troy which retranslates Virgil via Denham's earlier imitation of the Aeneid in Coopers Hill, see EH, p. 10. 


\section{The Destruction of Troy (1656)}

As already suggested, The Destruction of Troy, like the Coopers Hill 'B' Text, was likely prompted (at least in part) by a desire to mourn Charles in print. The invitation for readers to note the parallel between the decapitated body of Priam and the beheaded Charles also reveals affinities between The Destruction of Troy and the other single-book translations of the Aeneid that were published in the first half of the seventeenth century, all of which advance a political standpoint that was often, but not exclusively, royalist. ${ }^{85}$ In addition, framing the death of Priam in this manner provides a contemporary update to the politicized reading of the episode which has Virgil's Priam act as a stand-in for Pompey. Whilst it has particular connections with Denham's own stated aims as a translator of making Virgil speak 'not only as a man of this nation but as a man of this age', and so has an aesthetic as well as a political impulse, he was neither the first nor the last translator of Virgil to use the episode in this manner during this period. ${ }^{86}$ John Ogilby had used Priam's death to mourn Charles in his 1649 translation of Virgil; ${ }^{87}$ James Harrington's 1658 translation of Aeneid I-II refers to how Pyrrhus 'strikes off old Priam's head', when Virgil's Pyrrhus kills Priam with a sword-thrust to the torso. ${ }^{88}$ In The Destruction of Troy, Denham, like Ogilby and Harrington, creates a set of multiple associations between Priam, Pompey and Charles. Such associations are in turn comparable to the overlapping identifications between the stag, Strafford and Charles in Coopers Hill. Like this earlier technique, they provided a precedent that other writers used in their own compositions into the Restoration. ${ }^{89}$

As with the 'B' Text of Coopers Hill, the material form of The Destruction of Troy draws special attention to the passage that evokes Charles's death, but does so by making this passage act as the final section of the translation rather than by referring to it in a prefatory note. All of the other stand-alone renderings of individual books of the Aeneid that had been published by 1656 translated the relevant book in its entirety, so this strategy is not one Denham's first readers would have encountered previously. He may have been aware of Abraham Cowley's abandoned royalist epic The Civil War (1642-3), but this poem was never published in Denham's lifetime, and it is not known how extensively it circulated in manuscript. He was, though, more than aware of another abandoned epic that had been published, Davenant's Gondibert. Seventeenth-century editions of this poem,

\footnotetext{
85 See S. Brammall, The English Aeneid: Translations of Virgil, 1555-1646, Edinburgh, 2015, pp. 116-86, which discusses the translations of Aeneid I by George Sandys (1632), Sir Thomas Wroth's 1622 translation of Aeneid II (which like Denham's was titled The Destruction of Troy) and versions of Aeneid IV by Dudley Digges (1622) and John Stapylton (1634).

86 EAV, p. 132.

${ }^{87}$ For Ogilby's Priam, see Power, 'Teares breake off my Verse' (n. 17 above), p. 148.

88 James Harrington, An Essay Upon Two of Virgil's Eclogues and Two Books of his Aneis (if this be not enough) Towards the Translation of the Whole, London, 1658, p. 38. Harrington's Priam is discussed in Smith, Literature and Revolution (n. 6 above), p. 230.

89 H. Chalmers, Royalist Women Writers 1650-1689, Oxford, 2004, pp. 87-8, considers the parallels between Pompey and Charles that Katherine Philips includes in Pompey, her version of Pierre Corneille's La Mort de Pompée (1641), which was first performed in 1663.
} 
however, drew attention to its incomplete status, either through Davenant's own preface or a note from the volume's printer. A more distant precedent would be the publication of Marlowe's Hero and Leander with the editorial comment of 'Desunt nonnulla' ('much is missing') to explain the sense of an abbreviated conclusion. ${ }^{90}$ Gondibert and Hero and Leander indicate that poems with a seemingly fragmentary or incomplete status were usually signalled as such upon publication by the author, editor, or publisher. By contrast the 1656 edition of The Destruction of Troy does not give the impression that it contains only a partial translation of Aeneid II. Because 'FINIS' is printed after the last couplet, ${ }^{91}$ readers encountering this book of the poem for the first time in The Destruction of Troy would quite reasonably assume that the narrative does break off at the moment of Priam's death. For readers who did have previous knowledge of Aeneid II, either in the original or from an earlier translation, Denham's choice of ending ensures that the episode gains a greater topicality, extra attention and added pathos. It gives the impression that Denham was so emotionally overwhelmed by the death of Priam (or Charles-asPriam) that he was able to go no further. ${ }^{92}$ This would correspond to a composition date of the early 1650s and indicate that for Denham, and other royalists, the execution of Charles remained too painful and traumatic to be able to articulate fully or even adequately.

Crucially, though, by claiming it was 'Written in 1636', Denham places the origins of the translation twenty years before its publication, six years before the outbreak of hostilities in England and during the period royalist poets (both at the time and subsequently) liked to call the 'halcyon days', the era of supposed peace and prosperity of Charles's 'Personal Rule' prior to the outbreak of the civil wars. ${ }^{93}$ There is an addition potential resonance attached to 1636 within this context, as this was the year prior to the St Giles Riots in Edinburgh which is sometimes treated as the start-date of the first phase of the civil wars: 1636 was the last full year of the halcyon days, and so would retrospectively gain a particularly potent, melancholic status.

In presenting The Destruction of Troy as a work of 1636 Denham may be signalling a precedent established by his immediate predecessor as a Virgil translator, George Sandys. Sowerby has considered how Denham intended the manuscript translation as a continuation of Sandys's translation of Aeneid I, which

\footnotetext{
90 Christopher Marlowe, Hero and Leander, London, 1598, sig. E4 ${ }^{\mathrm{v}}$. This note only appears in the standalone edition, not the other edition of 1598, which prints Chapman's continuation of the poem.

91 Destruction of Troy, London, 1656, p. 28.

92 I have applied this interpretation from the reading of The Civil War in Power, 'Teares Break off my Verse' (n. 17 above). It is a lack of foresight that proved a major obstacle for Cowley's attempt to complete this epic, as even as he was writing the poem it became clear that there would be no more royalist victories to commemorate in verse. D. Trotter, Poetry of Abraham Cowley, London, 1979, p. 7, however, identifies aspects to the poem which ensured that the poem could not be completed even if the royalists had been more militarily successful.

93 For the literary culture of this period, see Wilcher, Writing of Royalism (n. 6 above), pp. 7-20.
} 
was published as a coda to the 1632 edition of his Metamorphoses. ${ }^{94}$ In that volume Sandys adds a prefatory 'To the Reader', which begins:

Divers yeares are now past since I began the Translation of Virgils AEneis, but finding it to heavy a burthen (my minde being also diverted from these studies) I gaue it over, even in the first entrance. ${ }^{95}$

The sense of continuity applies not just in terms of its content but also regarding Sandys's aesthetic and practical approach towards translation. Sandys's note also set a precedent of acknowledging a significant gap between composition and publication, and even an explanation for only providing a partial rendering in the first place: Englishing Virgil was too burdensome a task to do wholesale, at least for Sandys. The conclusion to the manuscript translation at Aeneid VI and the even more abrupt conclusion to The Destruction of Troy act as a similar acknowledgement of the burden growing too great for Denham. The implication is that Virgil is an author who can only be translated in fragments and that those attempts should then be laid aside. The accuracy of Sandys's statement cannot be established, but comparing The Destruction of Troy with Denham's earlier manuscript translation reveals the falsity of the claim that this version of Aeneid II dates from 1636. The significant differences between the manuscript as it survives in the Hutchinson commonplace book and the first edition of The Destruction of Troy stem more from a desire to introduce a prophetic element to the translation's lines on Priam than to stress the difficulty of (to adopt Denham's own metaphor) placing Virgil in English dress. $^{96}$

The Coopers Hill 'B' Text had established a precedent for Denham revising work from earlier in his career to grant an additional political commentary that would be even more potent if the date of original composition (instead of revision) was accentuated on publication. What connects the Coopers Hill ' $\mathrm{B}$ ' Text and The Destruction of Troy is not so much their shared status as poems which provide veiled elegies for Charles I, but that Denham used them to give the impression that he had predicted Charles's execution long before the event itself. The reference to the Virgil translation as a work of 1636 reasserts the clear parallels between the death of Priam and the death of Charles, even in the act of downplaying them, as does the claim that the 'B' Text of Coopers Hill with its 'allegory of the Royall stag' dates from 1640 rather than the early 1650 s.

Denham's wish to suggest that the Coopers Hill 'B' Text and The Destruction of Troy have prophetic elements raises similar questions of Virgilian predestination and agency previously discussed with regard to the 'A' Text. Here, though, the issue of agency refers primarily to Denham himself rather than to Charles. If Charles's death was as cataclysmic, but as pre-ordained, as the death of Priam and the fall of Troy, there was nothing more Denham and his fellow royalists could have done in

\footnotetext{
94 At $E A V$, p. 27 Sowerby posits that Denham, like Sandys, was a member of the circle of poet-translators that centred around Viscount Falkland and his estate at Great Tew in the 1630s and that the manuscript translation may have grown out of this association.

95 G. Sandys, Ovid's Metamorphosis Englished, Mythologiz'd, And Represented in Figures. An Essay to the Translation of Virgil's Eneis. By G.S., Oxford, 1632, p. 532.

96 EAV, p. 132.
} 
support of their cause. Presenting this as the state of affairs would grant consolation and self-justification to these royalists. They could preserve their pride, even if they gradually began to accommodate themselves to the new regime. Denham himself was sometimes perceived to be one of these figures, as Philip Major has referred to 'a rueful, if misplaced perception on the part of the royalists' that in 1653 'Denham had returned to England to become the de facto poet laureate of the Commonwealth'. ${ }^{97}$ Denham's position in England during the Protectorate was more ambiguous than this, and it is now thought that he returned from exile not only to reclaim lands (and income) that had been sequestered at the start of the civil conflict, but also to act as a royalist intelligencer. It is even possible that he acted as a royalist double agent. ${ }^{98}$

Whatever Denham's precise status was after 1653, there was ample material in Aeneid II that could be made to correspond with a sense of unwilling, but fatalistic, acceptance of the new regime. Throughout this book Aeneas is told repeatedly, first by the ghost of Hector, then his mother Venus and finally the ghost of his wife Creusa, that he has done enough for Priam and for Troy and should feel no guilt about fleeing the city. ${ }^{99}$ Venus not only tells Aeneas that Troy is fated to fall, but also shows him how it is occurring with the direct agency of the gods: Neptune overturns the Trojan walls that he himself helped to build, and both Juno and Athena urge on the Greek soldiers in their rout of the city. ${ }^{100}$ By breaking off the translation where he does, however, Denham is only able to incorporate Aeneas's encounter with Hector, and so his Aeneas does not receive the consolation that his departure from Troy is fated and divinely ordained. Nor is Denham able to incorporate the more hopeful ending of Aeneid II, where Aeneas leads a band of Trojan survivors to a new land. ${ }^{101}$ Whilst addressing the divine sanctioning of Troy's overthrow could have played into the hands of the new English republic's own mythmaking, other translations of Aeneid II by royalists that appeared in the aftermath of Charles I's execution use these elements of the poem to present his heir, Prince Charles (Charles II) as an Aeneas. Through this application, they prophesy a Stuart Restoration. Lawrence Venuti has identified a potential indication of royalist revival in Denham's addition of a phrase in the account of Priam's death that has no prompting in Virgil's Latin, since Priam is called 'the king, who yet survived the state'. ${ }^{102}$ Although Venuti's reading could potentially be applied to the survival of the monarchy (the Stuart line has survived the loss of their kingdom), Denham's emphasis is very firmly on the individual monarch rather than the institution. As a result, The Destruction of Troy draws on the source-text's fatalism for exclusively pessimistic purposes. Even if other royalists might have found consolation in reading The Destruction of Troy, there is, as Davis has argued, little evidence to

\footnotetext{
97 P. Major, 'Introduction', in SP, pp. 1-11 (5).

98 See $H D$, pp. 98-101, 113-22, 126-53.

99 See Virgil, Aeneid II.289-97 (Hector), II.601-3 (Venus), II.776-84 (Creusa).

100 Outlined in Venus's speech, ibid., II.604-18.

101 Ibid., II.796-804.

102 Destruction of Troy, 1. 542. See further Venuti, Translator's Invisibility (n. 4 above), p. 54.
} 
suggest that Denham found (re)translating Aeneid II to be a consoling or comforting experience. $^{103}$

An ultimately frustrated desire to find consolation in translating Virgil also informs the supposedly prophetic elements of The Destruction of Troy and, to some extent, Coopers Hill as well. This becomes apparent through Denham's treatment of the Trojan princess Cassandra, who appears in Aeneid II:

Tunc etiam fatis aperit Cassandra futuris ora, dei iussu non umquam credita Teucris. ${ }^{104}$

(Even then Cassandra revealed the future fates, [but] on the order of the god was not believed by the Trojans.)

Denham's 1636 manuscript version of these lines reads: 'Cassandra then our future fate revealed,/Which therefore less believed, being told, was more concealed.' 105 The equivalent couplet in The Destruction of Troy reads 'Cassandra then foretells th'event, but she/Finds no belief (such was the gods' decree)'. ${ }^{106}$ As Cassandra, like the Sibyl of Aeneid VI, did experience hindsight as foresight, it is tempting to interpret the Trojans in The Destruction of Troy as Priam's/Charles's subjects and Denham's Cassandra as the translator's self-portrait. ${ }^{107}$ Denham could have drawn some sense of vindication by presenting himself as someone who had foreseen the civil war and execution of Charles even in the fractious, though relatively peaceful, 1630 s, but was powerless to prevent these events from coming to pass. The prefatory materials to the Coopers Hill 'B' Text and The Destruction of Troy encourage this reading and so offer a similar (if less explicit) assertion of poetic authority that is contained in Milton's headnote to Lycidas in Poems. This account could apply as far as the English/Trojan parallel, since it would present the English as a people who had received a true prophecy of the future, but who did not hear it or recognize it as a prophecy until the events that it foretold had already come to pass.

Denham, however, only seems to align himself partially with Cassandra. Once again, an act which might be thought to enhance Denham's agency has the opposite effect once the fuller circumstances of the translation's composition are considered. Denham includes himself amongst those who have heard a prophecy, but who were not aware of its status as a prophecy until it was too late. Like Cassandra and the other prophets in the Aeneid, Denham acts as a vessel for a more powerful, omniscient being (Virgil/Apollo) but unlike them he is unaware of this status, and so

\footnotetext{
103 Discussed at Davis, Translation and the Poet's Life (n. 4 above), pp. 19-39.

104 Virgil, Aeneid II.246-7.

105 Denham, Aeneid II.231-2.

106 Destruction of Troy, 11. 236-7.

107 Such an approach would anticipate the comparison between the translator and a prophetess that occurs in Wentworth Dillon, 4th Earl of Roscommon's Essay on Translated Verse, London, 1684, p. 7. Roscommon's informal 'academy' of writers and translators was in many respects a successor to Falkland's Great Tew circle in terms of its literary aims and ambitions. Information about Roscommon and this academy is available in G. Clingham, 'Roscommon's "Academy", Chetwood's Manuscript "Life of Roscommon", and Dryden's Translation Project', Restoration, 26, 2002, pp. 15-26.
} 
is incapable of interpreting the message of what is spoken through him. Virgil speaks through Denham in The Destruction of Troy and in the stag-hunt passage of Coopers Hill, but Denham was not listening to, or not equipped to interpret, the truth that he was helping to articulate. The emphasis in both texts in these editions remains on mourning and on missed opportunities, which Denham himself has emphasized through the revisions he has made to them. Thanks to this status, The Destruction of Troy appears, even more so than the Coopers Hill 'A' Text, to be a work of criticism, even recrimination, rather than of consolation. Unlike the ' $A$ ' Text, Denham primarily directs this criticism not at Charles, but himself.

\section{Conclusion}

Denham continued to use The Destruction of Troy and Coopers Hill as a means of mourning Charles I and as sites of self-questioning after the Restoration. The two poems were published together in his Poems and Translations of $1668 .{ }^{108}$ It was also the first reissuing of both poems since the 1650s. The volume retains the prophetic status of The Destruction of Troy by reasserting a 1636 composition date on a separate title-page, although not in the initial table of contents. No date, either of composition or previous publication, is attached to Coopers Hill, and so it appears more straightforwardly as a commemorative poem. The text of The Destruction of Troy is unchanged, but Denham makes a couple of very minor changes to the ' $\mathrm{B}$ ' Text for this volume, which restore earlier ' $\mathrm{A}$ ' Text readings. ${ }^{109}$ What he does not do, however, is reinstate the prediction of royal supremacy that forms the conclusion to the 'A' Text. Nor does Denham add the final third of his Aeneid II translation to The Destruction of Troy. Both of these would provide more optimistic conclusions and would allow Denham to 'foretell' the re-assertion of Stuart authority, just as he had 'foretold' its downfall in the 1650s editions of both texts.

Denham's royalism was such that he would not have experienced the same type of personal unease or guilt under Charles II as Davis argues that he did under Cromwell. In 1660 Denham was, after all, made Surveyor of the King's Works, and soon after a Knight of the Bath and an MP, all of which suggest an active engagement with the Carolean regime and (from Denham's perspective) longoverdue rewards for past loyal service. It is nonetheless worth observing that, unlike other royalists who returned to England in the 1650s such as Davenant and Cowley, and indeed the majority of poets active in the early 1660s, Denham does not appear to have written any poetry on the occasion of the Stuart Restoration or Charles's

\footnotetext{
108 T. Caldwell, Virgil Made English: The Decline of Classical Authority, Basingstoke, 2008, pp. 46-8, considers the connections between the two texts which occur when they are printed sequentially in this edition.

109 There are individual word changes at 11. 1, 3, and 18, and an extra four lines added immediately after the Thames couplets (Coopers Hill [1668], 11. 193-6). As Denham died in 1669, Poems and Translations served as the basis for subsequent printings of each poem until $\mathrm{EH}$.
} 
coronation. ${ }^{110}$ The closest Denham came to doing so is in 'A Panegyrick upon His Excellency, the Lord General George Monck' from 1659, but the attribution is not definite, not least because it is absent from Poems and Translations. That volume opens with a dedicatory epistle to Charles II which contains a statement of Denham's service to the royal family in the years either side of Charles I's execution; but strikingly it makes no reference at all to the restoration itself. Revising Coopers Hill and his Virgil translation in the 1650s and republishing these works in the 1660s indicates the severity of the trauma Charles's death caused and how neither Denham nor the wider culture had been able to come to terms with it twenty years later, nearly a decade into the restoration of the monarchy under Charles's son. Continuing to recall Charles I in the hunted stag of Coopers Hill and Priam in The Destruction of Troy is symptomatic of how Denham felt he had compromised his sense of personal integrity between the 1640s and 1660s, and also of the larger fault-lines that ran through Restoration society that were ultimately never resolved.

Open Access This article is distributed under the terms of the Creative Commons Attribution 4.0 International License (http://creativecommons.org/licenses/by/4.0/), which permits unrestricted use, distribution, and reproduction in any medium, provided you give appropriate credit to the original author(s) and the source, provide a link to the Creative Commons license, and indicate if changes were made.

${ }^{110}$ See William Davenant, Poem, Upon his Sacred Majesties Most Happy Return to his Dominions, London, 1660, and A. Cowley, Ode Upon the Blessed Restoration and Returne of His Sacred Majestie, Charls the Second, London, 1660. 